\title{
archOnline@JCU
}

This is the Accepted Version of a paper published in the journal: International Journal of Drug Policy

Clough, Alan R., and Bird, Katrina (2015) The implementation and development of complex alcohol control policies in indigenous communities in Queensland

(Australia). International Journal of Drug Policy, 26 (4). pp. 345-351

http://dx.doi.org/10.1016/j.drugpo.2015.01.003

(C) 2015. This manuscript version is made available under the CC-BY-NC-ND 4.0 license

http://creativecommons.org/licenses/by-nc-nd/4.0/

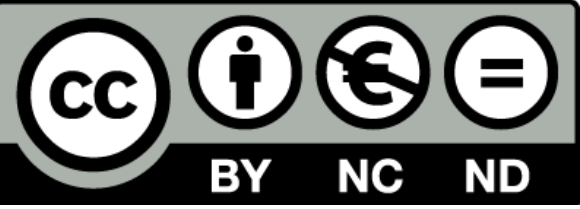


Accepted Manuscript

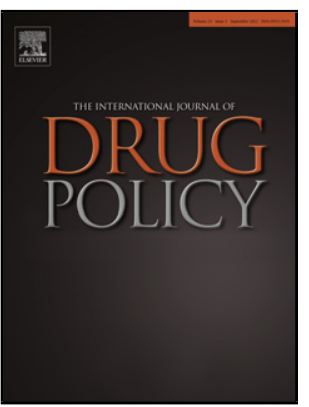

Title: THE IMPLEMENTATION AND DEVELOPMENT OF COMPLEX ALCOHOL CONTROL POLICIES IN INDIGENOUS COMMUNITIES IN QUEENSLAND (AUSTRALIA)

Author: Alan R. Clough Katrina Bird

PII:

DOI:

Reference:

S0955-3959(15)00006-7

DRUPOL 1510

To appear in: $\quad$ International Journal of Drug Policy

Received date: $\quad$ 17-7-2014

Revised date: 13-10-2014

Accepted date: $\quad$ 7-1-2015

Please cite this article as: Clough, A. R., and Bird, K.,THE IMPLEMENTATION AND DEVELOPMENT OF COMPLEX ALCOHOL CONTROL POLICIES IN INDIGENOUS COMMUNITIES IN QUEENSLAND (AUSTRALIA), International Journal of Drug Policy (2015), http://dx.doi.org/10.1016/j.drugpo.2015.01.003

This is a PDF file of an unedited manuscript that has been accepted for publication. As a service to our customers we are providing this early version of the manuscript. The manuscript will undergo copyediting, typesetting, and review of the resulting proof before it is published in its final form. Please note that during the production process errors may be discovered which could affect the content, and all legal disclaimers that apply to the journal pertain. 


\title{
THE IMPLEMENTATION AND DEVELOPMENT OF COMPLEX ALCOHOL CONTROL POLICIES IN INDIGENOUS COMMUNITIES IN QUEENSLAND
}

\author{
(AUSTRALIA)
}

Alan R Clough and Katrina Bird

\author{
Alan R Clough $(\mathrm{PhD})^{1,2}$ \\ Associate Professor \\ alan.clough@jcu.edu.au \\ Katrina Bird (BSc) ${ }^{1}$ \\ katrina.bird@jcu.edu.au
}

1. Community-based Health Promotion and Prevention Studies Group Australian Institute of Tropical Health and Medicine James Cook University, Cairns, Queensland, Australia, 4870

2. Corresponding author: alan.clough@jcu.edu.au Phone: +61 742321604 


\section{THE IMPLEMENTATION AND DEVELOPMENT OF COMPLEX ALCOHOL CONTROL POLICIES IN INDIGENOUS COMMUNITIES IN QUEENSLAND}

(AUSTRALIA)

Key words: Indigenous Australian, alcohol, alcohol policy.

\section{ABSTRACT: (300 words)}

Very high rates of injury and death during the 1990s were linked with increased alcohol availability and misuse in discrete Indigenous communities in rural and remote Queensland (Australia). To address widespread concerns about a public health crisis, from 2002, the Queensland Government implemented alcohol control strategies known as 'Alcohol Management Plans' (AMPs) in 19 of these communities. Although resources for prevention and treatment were promised, AMPs became increasingly focused on local prohibition, restricted access to alcohol and punitive measures for breaching restrictions. An examination of legislation, regulations, explanatory notes, and published documents indicates this focus evolved across four phases since 2002. The first phase, from 2002 to 2004, saw 'restricted areas' with alcohol 'carriage limits' introduced, restricting the amounts and types of liquor permitted within some communities. The second phase (2002 to 2007) featured evaluations and reviews by the Queensland Government bringing recommendations for more stringent controls. Additionally, beyond the 'restricted areas', licenced premises situated within the 'catchments' of the targeted communities, mainly located in the nearby regional towns, became subject to 'minimising harm' provisions. These more stringent controls were implemented widely in the third phase (2008 to 2011) when: the operations of seven 
community-managed liquor outlets were terminated; the trading arrangements of two others were modified; Police powers to search and seize were increased; and 'attempting' to take liquor into a 'restricted area' also became an offence. Some communities have seen a reduction in alcohol-related harms that have been attributed to these alcohol control strategies. This commentary maps the recent regulatory history of Queensland's alcohol controls targeting discrete Indigenous communities highlighting their increasing focus on punitive measures to reduce access to alcohol. With AMPs in Queensland currently under Government review, and with community resolve for change rising, the limits to Government controls and punitive measures may have been reached. 


\section{INTRODUCTION}

Alcohol Management Plans (AMPs) were first implemented in Queensland in 2002 under the policy banner of Meeting Challenges, Making Choices [MCMC]. From the outset, AMPs featured controls on the quantity and type of alcohol that could be legitimately possessed in most of the 19 discrete Indigenous (Aboriginal and Torres Strait Islander) communities located in rural and remote areas of northern and eastern Queensland (Figure 1) (Fitzgerald, 2001; Indigenous Communities Liquor Licences Bill 2002; Queensland Government [QGovt], 2002). In particular, the Queensland Government (the "Government") aimed to break the reliance of Local Government Councils ("Councils") on selling alcohol in Council-managed 'canteens' or taverns. Following reviews and evaluations conducted from within Government in 2005 and again in 2007, these controls were further tightened in 2008 under a new policy banner; Alcohol Reform Project, the stated purpose of which was to assist communities to "go as dry as possible" (p. 57) (QGovt, 2009). By early 2009 alcohol had become restricted in 12 of these communities and, with the closing of 'canteens', completely prohibited in seven communities (Figure 2) (Part 3 Aboriginal and Torres Strait Islander Communities (Justice, Land and Other Matters) and Other Acts Amendment Act 2008). Legislative changes made it an offence not only to possess liquor other than of a prescribed quantity and type, but also to attempt to take prohibited liquor into an AMP community. Alongside these more stringent place-based controls, across a wide area, 'minimising harm' strategies were brought into play designed to limit alcohol sales from the 162 'catchment' licenced premises located, for the most part, in non-Indigenous service centres and towns situated near the 19 communities (Figure 1) (Department of Justice and Attorney General [DJAG], 2012). 
The State election in March, 2012, brought a change of Government in Queensland. The newly-elected Government had already promised during the election campaign to review AMPs, and it recently announced its review process (Liberal National Party of Queensland, unknown). However, at this important turning point in the controversial history of alcohol controls targeting Queensland's Indigenous communities, the regulatory mechanisms and policy processes used to implement AMPs have not been systematically documented. To begin to address this lack, and to inform policy makers and community leaders, this commentary maps the regulatory and legislative structures, instruments and processes which have underpinned Queensland's AMPs since 2002 (Figure 2). Their scope and complexity and their increased focus on enforcement and punitive measures to control access to alcohol are highlighted.

\section{APPROACH AND METHODS}

This commentary is not a systematic critical appraisal of Queensland's alcohol management policies for Indigenous communities. A full evaluation of their impacts and community responses will be the subject of further, more-detailed policy analyses. To provide a basis for such analyses, the available Queensland legislation, regulations, amendments, explanatory notes and published documents were examined. No single electronic compilation of relevant documents is available. To identify relevant documents, an exhaustive search through the currently available on-line documents was combined with a manual search for documents held in libraries, retained in our own libraries and in the collections of collaborating researchers and officers of Government departments. Original source documents such as original reports, policy statements, Acts of Parliament and Regulations, bills for proposed legislation and supporting explanatory notes were sought. The authors independently examined these documents. 
Alcohol restrictions were not implemented in the same way and at the same time in each of the targeted communities (Clough et al., 2014). In order to clarify the basis for their implementation and development, using the evidence available in the discovered documents, the authors independently mapped the main legislative and regulatory features of AMPs, and the timing of their implementation, across the targeted communities. By consensus, the authors identified four phases of AMP implementation and development of around three years each, since 2001. These phases are depicted in Figure 2 and summarised in the following narrative.

\section{PHASES OF REGULATION AND CONTROL}

\section{Prelude to 2002:}

Successive Governments over more than 40 years have attempted to address alcoholrelated violence and injury in Queensland's Indigenous communities. In the early 1970s, the Government attempted to provide legislated powers for locally-elected community organisations to control alcohol. The Aborigines Act 1971 gave Queensland's Governor in Council the power to establish Aboriginal Councils on Aboriginal reserves and the Director of Aboriginal and Island Affairs could establish premises specifically for the sale and supply of "beer". The Community Services (Aborigines) Act 1984, repealed the Aborigines Act 1971, designated these reserves as Indigenous trust areas and gave the local Aboriginal Councils the ability to introduce premises for the sale and supply of "beer" in their trust area (PART VIII- (1) Community Services (Aborigines) Act 1984). The term 'canteen' is used to describe these premises. Additionally, the Community Services (Aborigines) Act provided Councils the ability to make by-laws relating to law and order and community justice (Martin, 1998). Many Councils passed by-laws under this Act and attempted to operationalise controls (QGovt, 2013). 
The operation of 'canteens' brought significant finances to the Councils which typically had few revenue-raising opportunities to fund community activities and services (Hudson, 2011; Martin \& Brady, 2004). This created a conflict of interest for Councils (Martin, 1998; Martin \& Brady, 2004); on the one hand, raising revenue from selling alcohol while, at the same time, responsible for enacting by-laws for peace, order and community safety (Martin, 1998). Community efforts to address local alcohol issues using locallydeveloped strategies have largely gone unrecognised. In the community of Aurukun, in the far north of Cape York, its Council dominated by non-drinking women exercised their powers and closed the Aurukun canteen in 1991 in response to unacceptable levels of violence (Martin, 1998). Uniquely documented are the efforts to manage this conflict by the 'Aurukun Alcohol Law Council,' introduced in 1995 through amendments to the Local Government (Aboriginal Lands) Act 1978. In Aurukun, under the Local Government (Aboriginal Lands) Act 1978, both public and private places could be declared as either "controlled" or "dry" by the Aurukun Alcohol Law Council; restrictions could also be placed on the type and/or quantity of alcohol carried in vehicles on public roads (Martin, 1998).

However, such efforts were overshadowed as increased alcohol availability across the communities was followed by mounting anecdote and systematic evidence that very high levels of alcohol consumption were compromising community safety, health and welfare (Martin, 1998; Martin \& Brady, 2004). A distressing rise was documented in alcohol-related violence (Aboriginal and Torres Strait Islander Women's Task Force on Violence, 2000) and injury (Gladman, Hunter, McDermott, Merritt, \& Tulip, 1998).

This emerging evidence reinforced the vigorous advocacy of Indigenous leaders (Pearson, 2001), and was echoed in the Cape York Justice Study, 2001 [CYJS], where Justice Tony Fitzgerald, after community consultation and deliberation, concluded that alcohol, substance abuse and violence were threatening the viability of Cape York Indigenous 
communities (Fitzgerald, 2001). The CYJS recommended a new approach to targeted intervention, community development and public sector reform to enable community development to take place for a better quality of life in these localities (Fitzgerald, 2001).

\section{Phase 1: 2002-2004 - Meeting Challenges, Making Choices}

The release of the CYJS prompted responses from the Councils of Aurukun, Umagico, Pormpuraaw, Hope Vale and Kowanyama (Aboriginal Co-ordinating Council Newsletter [ACC Newsletter], 2002; Hope Vale Aboriginal Council, 2002; Kowanyama Aboriginal Council, 2002; Pormpuraaw Community Council, 2002; Umagico Aboriginal Council, 2002) (Figure 1). Hope Vale was the only council that did not have a Councilmanaged 'canteen'. These Councils strenuously argued that the CYJS had treated social and economic problems in Cape York communities at a superficial level (ACC Newsletter, 2002). They believed the community consultation process of the CYJS was flawed, declaring that they did not support the recommendations for alcohol controls, particularly the proposed changes to 'canteen' licensing (ACC Newsletter, 2002).

MCMC was the Government's response to the CYJS. Three community-level strategies were specified in MCMC: i) restricting alcohol availability through alcohol management plans; ii) demand reduction strategies: including rehabilitation, treatment and diversion initiatives; and iii) removing 'canteen' management from Councils (MCMC, 2002).

Restricting alcohol availability in AMP communities was to be done in consultation with Community Justice Groups (CJGs) (Liquor Act 1992). CJGs were formed in targeted communities as statutory bodies under the Aboriginal Communities (Justice and Land Matters) Act 1984 and the Community Services (Torres Strait) Act 1984 with legislated responsibilities to advise on alcohol issues within their communities under the Liquor Act 1992 (the "Liquor Act") (KPMG, 2010). These responsibilities included providing recommendations on the type and quantity of alcohol allowed for each community and the 
community area(s) where restrictions should apply (Aboriginal Communities (Justice and Land Matters) Act 1984; Community Services (Torres Strait) Act 1984; Hudson, 2011). Members of CJGs, volunteers appointed by the Minister, were also given power under the Community Services Legislation Amendment Act 2002 to declare areas 'restricted' or 'dry'. The appointed CJGs provided Government an advisory mechanism to inform liquor legislation and regulation, and an important source of policy influence alternative to the elected Councils.

The Liquor Act and Liquor Regulation 2002 regulate the sale and supply of liquor in Queensland generally and specify the penalties associated with breaches. Part 6A, S173G and $\mathrm{S} 173 \mathrm{H}$ of the Liquor Act allow a regulation to declare an area "restricted" and to prescribe the quantities and types of liquor which people may have in their possession in the restricted area. The areas restricted and the prescribed quantities and types of liquor are described in Schedules 1A-1R of the Liquor Regulations 2002. Section 168B of the Liquor Act makes it an offence to have in one's possession more than the prescribed amount or type of liquor in a restricted area. Up to 2008 , S168B related only to public places within the restricted area (Aboriginal and Torres Strait Islander Communities (Justice, Land and Other Matters) and Other Acts 2008). An unanticipated constraint on enforcing this provision was that Police had no power in the circumstance where illicit alcohol had been brought into a restricted area undetected and kept within the confines of a private residence.

With some Councils resisting strongly and with much debate between Councils and the Government, particularly about the respective powers and influence of elected Councils versus appointed CJGs, AMPs were not implemented in all communities simultaneously (Figure 2). While the implementation process was unfolding, communities continued their attempts, albeit with little apparent success, to control alcohol through local by-laws (QGovt, 2013), which remained in place until each AMP was implemented. 
The last of the 19 AMPs commenced on 19 June, 2006 on Palm Island, three and a half years after the MCMC policy (see Figure 2). For Palm Island, at least four draft AMPs were prepared during 2004, but no agreement could be reached between the Government, the Council and the CJG (Liquor Amendment Regulation (No. 4) 2006). After these years of unsuccessful negotiation, Queensland's Minister for Aboriginal and Torres Strait Islander Policy prepared an outline based on the four drafts to form Palm Island's AMP, specifically, Schedule 1R of the Liquor Regulation 2002 (Liquor Amendment Regulation (No. 4) 2006).

\section{Phase 2: 2005-2007 - a period of review and 'harm minimisation' strategies}

In its 2005 review of the MCMC policy, the Government recognized and declared that, of the three elements of the MCMC program design, only supply restrictions and their enforcement had been implemented (QGovt, 2005). This large and complex review pointed to perceived trends towards normalizing community life in some affected communities along with a reduction in the numbers of hospital presentations for assault and injury in other communities. Despite this positive evidence, robust baseline measures were lacking for convincing conclusions to be made that AMPs had been effective in all targeted localities. A principal outcome of the 2005 review was to establish a focus within the Government on the need to overcome Indigenous disadvantage generally, and consequently, the specific matter of AMPs became wrapped within a suite of other Government programs in Indigenous communities. This new policy package was named Partnerships Queensland, built it seems on the notion of changing "ways of doing business with communities" (p4) (QGovt, 2005).

In 2007, a 'Whole of Government Review' of all its alcohol and other substances policies, programs and services was initiated by the Government as a prelude to finally removing the ability for Councils to hold liquor licences and operate 'canteens'. This review identified gaps in legislative responses, including the aforementioned constraints on Police powers with respect to alcohol possessed in private residences within restricted areas as, up to 
this time, restrictions had only applied to public places inside restricted areas (Aboriginal and Torres Strait Islander Communities (Justice, Land and Other Matters) Amendment Regulation (No. 2) 2008; Aboriginal and Torres Strait Islander Communities (Justice, Land and Other Matters) and Other Acts Amendment Bill 2008). In contrast with the earlier, more positively-framed MCMC review, this 'Whole of Government' review found no sufficient improvement in levels of harm, and it stressed the need to further tighten restrictions. It also stressed that separating the management of 'canteens' from councils had not occurred due to strong resistance by the Councils operating licences (Aboriginal and Torres Strait Islander Communities (Justice, Land and Other Matters) and Other Acts Amendment Bill 2008). The Bill stressed the:

“inappropriateness of local government social services being reliant on the level of profit from a business whose purpose is to sell alcohol, particularly when alcoholrelated harm is driving the need for those services" (p9) (Aboriginal and Torres Strait Islander Communities (Justice, Land and Other Matters) and Other Acts Amendment Bill 2008).

As a result of the review, with the aim to further tighten controls on alcohol availability, from 2005-06, 'minimising harm' conditions provided for in the Indigenous Communities Liquor Licences Bill 2002 (DJAG, 2012), were implemented for 'catchment' licenced premises, i.e. liquor outlets located within a few hours travel of a community in which alcohol restrictions apply. According to the 2010-11 Liquor and Gaming report, there were 162 premises located in these 'catchment' areas (Figure 1) (DJAG, 2012), distributed over approximately three quarters of a million square kilometres of Queensland (Figure 1). To reduce the opportunity for community members to purchase alcohol and return to their community intoxicated and/or carrying other than prescribed quantities and types, 148 of the 162 'catchment' licenced premises are required to comply with conditions such as: "cannot 
knowingly sell to someone travelling to a restricted area" (121 licenced premises); "required to maintain a 'bulk sale' register" (74 licenced premises), and "a limit on takeaways, other than port" (23 premises) (DJAG, 2012).

These more aggressive reviews and strategies in Queensland emerged in parallel with uncompromising and more focused policy initiatives at the national level to address Indigenous disadvantage generally in Australia, once and for all. In June 2007, a Northern Territory (NT) 'Board of Inquiry into the Protection of Aboriginal Children from Sexual Abuse' reported to the NT Chief Minister. The Board's report and the 'rivers of alcohol', sexual abuse and family violence it decried (Little children are sacred, 2007) triggered the Commonwealth's internationally-controversial Northern Territory National Emergency Response (NTER) legislation (Australian Human Rights Commission, 2013) [Commission]. The NTER legislation applied to 'prescribed areas' with bans on the sale and consumption of alcohol a defining feature. The effect of the NTER legislation fell on community living areas in and near towns ("town camps") and on the very remote Indigenous communities in the NT (Commission, 2013). The very remote NT communities are similar in many respects to the Queensland communities targeted for AMPs. The historic Apology to the Stolen Generations by the Australian Parliament in February 2008, was followed by the Council of Australian Governments (all States, Territories and the Commonwealth) National Partnership Agreement on Closing the Gap in Indigenous Health Outcomes, 'within a generation' (Council of Australian Governments [COAG], 2008).

\section{Phase 3: 2008-2010: 'as dry as possible'}

The Queensland Government, in its response to the national Closing the Gap strategy, focused on addressing problems of violence and substance abuse in Indigenous families and communities (QGovt, 2009). The Queensland Government interpreted its response as addressing a perceived 'community safety gap' with its Safer Communities initiative (QGovt, 
2009). Under this policy banner, "alcohol management reforms" (p. 55) became part of a new assemblage of strategies addressing: welfare reform, child protection, youth detention, family violence, plus "29 additional police officers in Indigenous communities” (p. 57) (QGovt, 2009). Further intensification of alcohol restrictions commenced in February 2008 with Queensland's Alcohol Reform project dedicated to making communities “as dry as possible" (p. 57) (QGovt, 2009). This included further strengthening of legislation through the introduction of the Aboriginal and Torres Strait Islander Communities (Justice, Land and Other Matters) and Other Acts Amendment Act 2008, which enhanced enforcement capacities and provided even tighter controls on availability using the following legislative and regulatory measures:

The Liquor Act:

- Insertion of S106 (4): Aboriginal Councils could no longer hold a liquor licence. Total prohibition in seven communities was created when the Council holding the licence either surrendered their licence or could not find an alternative suitable private licensee before 31 December, 2008 (see Figure 2),

- Insertion of S168C: attempting to bring alcohol into a restricted area, became an offence, permitting Police to lay charges against people intending to enter a restricted area with prohibited quantities or types of alcohol as well as charges for possessing it, under S168B,

- Insertion of S168C (2): the bona fide traveller exemption, permitting those transiting through, but not stopping in, restricted areas to carry more than the prescribed amounts,

- Amendment to S168B (1): Private residences became subject to carriage limits, increasing the enforcement options for Police within restricted areas, 
- Amendment to S168B (1): Drinking in a public place became generally prohibited, making obsolete the power of the CJGs to make dry place declarations for specific public areas;

The Aboriginal and Torres Strait Islander Communities (Justice, Land and Other Matters) Act 1984:

- Replacement of Part 5, Division 3: Banned home brew and home brew equipment, as home-made alternatives to commercial forms of alcohol were reportedly being produced in some communities,

- Replacement of Part 5, Division 2: Allowed residents of communities with carriage limits to apply for their house to be considered a "Dry Place";

The Police Powers and Responsibilities Act 2000

- Insertion of S30(a)(ix): Police became empowered to search without a warrant if they suspected a person of holding more than the prescribed types or amounts of alcohol, enabling greater discretion to enter private homes in targeted communities.

\section{Phase 4: 2011-2013 - 'exit' strategies, elections and promised reviews}

In this phase, the Government looked to the elected Councils once more to provide a way forward to manage alcohol in their communities. In the lead-up to the March 2012 State election, from early 2011, the former Government heralded this significant shift when it advised Councils through the State's peak Local Government body, the Local Government Association of Queensland (LGAQ), that it was seeking an 'exit strategy' from AMPs, promising to review restrictions if targeted reductions in harm indicators could be reached and sustained through Community Safety Plans (Figure 2) (Clough et al., 2014).

Important developments in empowering Indigenous Councils were accelerating from around this time. Towards the end of 2011, the annual conference of the LGAQ resolved to 
create a forum comprised of Indigenous Mayors and Council executive staff, called the Indigenous Leaders' Forum (ILF) (Clough et al., 2014). The LGAQ conference went on to pass a resolution, put by the ILF, calling for a review of AMPs in Indigenous communities. The resolution was supported by all 73 Queensland Councils at the conference, an unprecedented statement of support from mainstream Local Government for an Indigenous issue from across the whole jurisdiction (Clough et al., 2014).

The new Queensland Premier, during the election campaign, also committed to a review of AMPs to commence by the end of 2012 (see Figure 2) (Queensland, unknown). Its approach, led by the Minister for Aboriginal and Torres Strait Islander and Multicultural Affairs, makes each community responsible for its own review whether changes are desired or not (QGovt, 2012). Proposals for any modifications to an AMP are initially to be the responsibility of the Council in each affected community (QGovt, 2012), with CJGs playing a consultative, not determining, role. Among other criteria, the Government will consider submissions from Councils as long as it is demonstrated that they have consulted with all stakeholders, including CJGs (QGovt, 2012). Through a further consultation process, it is promised that Government representatives will assist each community to develop a transition plan for consideration for approval by the Government (QGovt, 2012).

This significant shift in the Government's position may have been a response, at least in part, to a series of challenges to the legitimacy of S168B of the Liquor Act. In May 2008, an Aboriginal resident of Palm Island was charged for a breach of S168B but subsequently appealed the charge in the District Court of Queensland and the Court of Appeal of Queensland's Supreme Court. The appeal argued that $\underline{\text { S168B }}$ of the Liquor Act was "invalid by reason of inconsistency with $\underline{s 10}$ " of the $\underline{\text { Racial Discrimination Act }}(\underline{1975})$ )" (p 1) (Maloney v The Queen). Section 10 of the Racial Discrimination Act (1975) ("RDA") is intended to ensure that State laws do not adversely affect or limit the enjoyment of rights by 
any racial group. This appeal was dismissed by Queensland's Court of Appeal in 2011 on the basis that $\mathrm{S} 168 \mathrm{~B}$ of the Liquor Act was a "special measure" under S8 of the RDA; i.e. a measure taken for the sole purpose of securing the advancement of a racial group, protecting it so that it can enjoy or exercise fundamental rights and freedoms generally. In 2012, the High Court of Australia granted special leave for an appeal of this decision. The High Court examined the interactions between S8 and S10 of the RDA and in July 2013 unanimously dismissed the Palm Island appeal finding the provisions of the Liquor Act restricting possession of alcohol on Palm Island did constitute a 'special measure'.

\section{CONCLUSION}

Queensland's strategies to control alcohol in Indigenous communities have featured ever-more-intense and complex techniques to restrict alcohol availability, but appear to be coming full circle with community resolve for change rising. Phase 1 featured controls on access to alcohol in a number of communities. Phase 2 saw the expansion of these controls to all targeted communities. Phase 3 brought the beginnings of attempts to control access to alcohol across a much wider region with controls on licensed premises in the "catchment areas', the closing of community 'canteens' and significantly-enhanced powers of enforcement. Phase 4 has seen successive Governments, of both liberal and conservative persuasion, seeking ways out of an ever-tightening and controversial array of regulations and provisions to reduce alcohol availability.

Alcohol-related violence and injury remain ongoing concerns in Indigenous communities across Australia (Australian Government, 2011; Doran et al., 2008; Gray, Saggers, Wilkes, Allsop, \& Ober, 2010; Martin \& Brady, 2004; Pearson, 2001; QGovt, 2005; Saggers \& Gray, 1997; Smith et al., 2013). While there may have been favourable impacts at first, the evidence that Queensland's alcohol control strategies have had sustained, favourable impacts across all communities is becoming equivocal. Corroborating the Queensland 
Government's evidence (QGovt, 2005, 2010, 2011a), there is some published data describing a decline in the rate of serious injuries occurring in a small group of isolated communities in Cape York during 1995-2010 (Margolis, Ypinazar, \& Muller, 2008; Margolis, Ypinazar, Muller, \& Clough, 2011) with these rates dropping by half in 2002-03 (Margolis et al., 2008) and falling to historically low levels after 2008 (Margolis et al., 2011). However, because of a dearth of systematic evidence for all affected communities, towns and regions, and because the outmigration of people from communities in response to intensifying restrictions and their enforcement remains undocumented, it is unclear whether similar favourable changes have occurred generally.

Irrespective of such possible successes, there are still no impactful policies or programs in place to support demand reduction, rehabilitation, treatment and diversion as originally committed. The proposed review of AMPs, announced in 2012, is very timely. It furnishes an important, perhaps unique, opportunity for comprehensive engagement and consultation with the Indigenous populations affected by AMPs and the relevant stakeholders. It also provides the opportunity for appropriate support services to be designed, implemented and made operational in affected communities before current restrictions are altered in any way. The limits to Government control over alcohol in Queensland's Indigenous communities appear to have been reached. A thoughtful policy revision would ideally retain any successful elements of AMPs but also be wary of any unforeseen consequences. 


\section{ACKNOWLEDGEMENTS}

The research conducted for this commentary was supported by the National Health and Medical Research Council of Australia (NHMRC, Project Grant APP1042532). The Collaborating Investigators on this project grant are: Professor Steven Margolis, Associate Professor Reinhold Muller, Professor Adrian Miller, Associate Professor Anthony Shakeshaft, Professor Chris Doran, Laureate Professor Rob Sanson-Fisher, Professor Robyn McDermott, Dr Valmae Ypinazar and Mr Simon Towle. Associate Professor Clough holds a NHMRC Career Development Award (APP1046773). The authors thank Ms Bronwyn Honorato, Ms Michelle Fitts, Ms Jan Robertson, Dr Caryn West, Dr Valmae Ypinazar, Dr David Martin, Associate Professor Reinhold Muller and Professor Steven Margolis specifically for their comments on the manuscript. The input of Mr Nicholas Roberts, Ms and Kim Robertson is also appreciated. Support is also gratefully acknowledged from the Australian Primary Health Care Research Institute-funded Centre for Research Excellence for the Prevention of Chronic Conditions in Rural and Remote High Risk Populations at James Cook University and the University of Adelaide (Professor Robyn McDermott, Chief Investigator).

Funding bodies had no role in the concept for this commentary, in the collection, analysis or interpretation of information, in the writing of the manuscript or the decision to submit the manuscript for publication. 


\section{REFERENCES}

Aboriginal and Torres Strait Islander Communities (Justice, Land and Other Matters) Act 1984 (Q1d) (Austl.).

Aboriginal and Torres Strait Islander Communities (Justice, Land and Other Matters) Amendment Regulation (No. 2) 2008 (Qld) (Austl.).

Aboriginal and Torres Strait Islander Communities (Justice, Land and Other Matters) and Other Acts Amendment Act 2008 (Qld) (Austl.).

Aboriginal and Torres Strait Islander Communities (Justice, Land and Other Matters) and Other Acts Amendment Bill 2008 (Qld) (Austl.).

Aboriginal and Torres Strait Islander Women's Taskforce on Violence Report (2000)

Brisbane: Department of Aboriginal and Torres Strait Islander Policy and Development, Queensland Government.

Aboriginal Co-ordinating Council Newsletter (2002). Summary of community responses to Cape York Justice Study Report, Aboriginal Co -ordinating Council Newsletter Special Ed April 2002. Retrieved from http://www.parliament.qld.gov.au/documents/TableOffice/TabledPapers/2002/5002T23 $\underline{69 . p d f}$

Aboriginal Communities (Justice and Land Matters) Act 1984 (Qld) (Austl.).

Aboriginies Act 1971 (Qld) (Austl.).

Australian Bureau of Statistics. (2011). Census: Community Profiles. Retrieved 27th of June, 2014, from Commonwealth of Australia http://www.abs.gov.au/websitedbs/censushome.nsf/home/communityprofiles?opendocu $\underline{\text { ment } \& \text { navpos }=230}$ 
Australian Government. (2011). Stronger Futures in the Northern Territory Report on Consultations October 2011. Canberra: FHCSIA Retrieved from http://www.dss.gov.au/sites/default/files/documents/09_2012/stronger-futuresconsult_1710111_0.pdf

Australian Human Rights Commission. (2013). The suspension and reinstatement of the RDA and special measures in the NTER. Retrieved from https://www.humanrights.gov.au/publications/suspension-and-reinstatement-rda-andspecial-measures-nter-1

Child Protection Act 1999 (Qld) (Austl.).

Clough, A. R., Fitts, M. S., Robertson, J. A., Shakeshaft, A., Miller, A., Doran, C. M., . . West, C. (2014). Study Protocol--Alcohol Management Plans (AMPs) in remote indigenous communities in Queensland: their impacts on injury, violence, health and social indicators and their cost-effectiveness. BMC Public Health, 14, 15. doi:

$10.1186 / 1471-2458-14-15$

Commission for Children and Young People and Child Guardian. (2014). Retreived from http://www.ccypcg.qld.gov.au

Community Services (Aborigines) Act 1984 (Q1d) (Austl.).

Community Services (Torres Strait) Act 1984 (Qld) (Austl.).

Council of Australian Governments. (2008). Closing the gap in Indigenous disadvantage. Canberra: Council of Australian Governments Retrieved from https://www.coag.gov.au/closing the_gap_in_indigenous_disadvantage.

Department of Aboriginal and Torres Strait Islander and Multicultural Affairs. (2010). Annual Highlights Report for Queensland's Discrete Indigenous Communities July 2009 - June 2010. Retrieved from 
http://www.datsima.qld.gov.au/resources/datsima/atsis/government/programsinitiatives/reports/annual-highlights-jul09-jun10.pdf

Department of Aboriginal and Torres Strait Islander and Multicultural Affairs. (2011).

Annual Highlights Report for Queensland's Discrete Indigenous Communities July 2010 - June 2011. Retrieved from http://www.datsima.qld.gov.au/resources/datsima/atsis/government/programsinitiatives/reports/annual-highlights-jul10-jun11.pdf

Department of Aboriginal and Torres Strait Islander and Multicultural Affairs. (2013). Annual Bulletin for Queensland's Discrete Indigenous Communities: 2011/12.

Department of Justice and Attorney General. (2012). Liquor and gaming report 2010 - 2011. Retrieved from http://www.olgr.qld.gov.au/_data/assets/pdf_file/0013/250240/OLGR_Liquor_and_G aming_Report_2010-11.pdf

Doran, C., Vos, T., Cobiac, L., Hall, W., Asamoah, I., Wallace, A., Naidoo, S., Byrnes, J., Fowler, G. and Arnett, K. (2008) Identifying cost-effective interventions to reduce the burden of harm associated with alcohol misuse in Australia. Brisbane, Qld, Australia: The University of Queensland

Fitzgerald, T. (2001). Cape York justice study. The situation of Cape York Indigenous communities. Queensland Department of the Premier and Cabinet, Brisbane.

Gladman, D. J., Hunter, E., McDermott, R. A., Merritt, T. D., \& Tulip, F. J. (1998). Study of injury in five Cape York communities April 1997. Adelaide: AIHW National Injury Surveillance Unit.

Gray, D., Saggers, S., Wilkes, E., Allsop, S., \& Ober, C. (2010). Managing alcohol-related problems among Indigenous Australians: what the literature tells us. Aust $N Z J$ Public Health, 34 Suppl 1, S34-35. doi: 10.1111/j.1753-6405.2010.00550.x 
Hope Vale Aboriginal Council. (2002). Hope Vale Aboriginal Council response to Cape York Justice Study recommendations. Retrieved from http://www.parliament.qld.gov.au/documents/TableOffice/TabledPapers/2002/5002T23 67.pdf

Hudson, S. (2011). Alcohol restrictions in Indigenous communities and frontier towns. Policy Monograph 116. Centre for Indepenent Studies: St Leonards. Retrieved from http://test.cis.org.au/images/stories/policy-monographs/pm-116.pdf

Indigenous Communities Liquor Licences Bill 2002 (Qld) (Austl.).

Kowanyama Aboriginal Council (2002, 4 March 2002). Fitzgerald Report Responses. Retrieved from http://www.parliament.qld.gov.au/documents/TableOffice/TabledPapers/2002/5002T23 $\underline{68 . p d f}$

KPMG. (2010). Department of Justice and Attorney General. Evaluation of the Community Justice Group Program: Final Report. Retrieved from http://www.justice.qld.gov.au/ data/assets/pdf file/0003/88905/evaluation-of-thecommunity-justice-group-program.pdf

Liberal National Party of Queensland (unknown). LNP CANDO ACTION: Responsible Alcohol Management - A community approach. Retrieved from http://lnp.org.au/wpcontent/uploads/attachments/AlcoholManagement.pdf

Liquor Act 1992 (Qld) (Austl.).

Liquor Amendment Regulation (No. 4) 2006 (Qld) (Austl.).

Maloney v The Queen (2013). High Court of Australia, 28, 19 June 2013, B57/2012

Margolis, S. A., Ypinazar, V. A., \& Muller, R. (2008). The impact of supply reduction through alcohol management plans on serious injury in remote indigenous communities 
in remote Australia: a ten-year analysis using data from the Royal Flying Doctor Service. Alcohol and alcoholism, 43(1), 104-110. doi: 10.1093/alcalc/agm152

Margolis, S. A., Ypinazar, V. A., Muller, R., \& Clough, A. (2011). Increasing alcohol restrictions and rates of serious injury in four remote Australian Indigenous communities. Medical Journal of Australia, 194(10), 503-506.

Martin, D. (1998). The supply of alcohol in remote Aboriginal communities: potential policy directions from Cape York: Centre for Aboriginal Economic Policy Research Canberra.

Martin, D., \& Brady, M. (2004). Human rights, drinking rights? Alcohol policy and Indigenous Australians. Lancet, 364(9441), 1282-1283. doi: 10.1016/S01406736(04)17147-X

Pearson, N. (2001). Outline of a grog and drugs (and therefore violence) strategy. Cape York Partnerships and Apunipima Cape York Health Council. Retrieved from http://www.cyp.org.au/downloads/noel-pearson-papers/outline-of-grog-and-drugsstrategy-010701.pdf

Pormpuraaw Community Council (2002). Council Response: Justice Study (Fitzgerald Report) November 2001 and Consultations. Retrieved from http://www.parliament.qld.gov.au/documents/TableOffice/TabledPapers/2002/5002T23 $\underline{65 . p d f}$

Queensland Government (1999). The Aboriginal and Torres Strait Islander women's task force on violence report. Department of Aboriginal Torres Strait Islander Policy. Queensland Government. (2002). Meeting Challenges, Making Choices: The Queensland Government's response to the Cape York Justice Study. Queensland: Department of Aboriginal and Torres Strait Islander Policy. Retrieved from http://www.parliament.qld.gov.au/documents/TableOffice/TabledPapers/2002/5002T23 81.pdf 
Queensland Government. (2005). Meeting Challenges, Making Choices Evaluation Report (pp. 185). Brisbane: Department of Aboriginal and Torres Strait Islander Policy.

Queensland Government. (2009). Queensland Closing the Gap Report: 2008/09: Indicators and Initiatives for Aboriginal and Torres Strait Islander Peoples. (1861-09). Brisbane: Retrieved from http://www.datsima.qld.gov.au/resources/datsima/atsis/government/programsinitiatives/closing-gap/2008-09-annual-report/closing-the-gap-0809-full.pdf.

Queensland Government. (2011). Just futures 2012-2015 summary: growing community, family, opportunity and justice for Aboriginal and Torres Strait Islander Queenslanders. Brisbane: Queensland Government, Retrieved from http://www.cabinet.qld.gov.au/documents/2011/sep/atsi\%20justice\%20strategy/Attac hments/Att\%202\%20Justice\%20Strategy\%202012-2015\%20Summary.PDF.

Queensland Government. (2012). Review of Alcohol Management Plans. Retrieved from http://www.datsima.qld.gov.au/datsima/aboriginal-torres-straitislander/government/programs-and-initiatives/review-of-alcohol-management-plans$\underline{2012}$

Queensland Government. (2013). Local Laws Database,. Retrieved 19 June, 2014, from http://www.dlg.qld.gov.au/information-for-local-governments/local-laws-onlinedatabase.html

Saggers, S., \& Gray, D. (1997). Supplying and promoting 'grog': the political economy of alcohol in Aboriginal Australia. Australian Journal of Social Issues, 32(3), 215-237.

Smith, K., Langton, M., d'Abbs, P., Room, R., Chenhall, R., \& Brown, A. (2013). Alcohol management plans and related alcohol reforms. Indigenous Justice Clearing House, 16. Retrieved from http://indigenousjustice.gov.au/briefs/brief016.pdf 
Umagico Aboriginal Council (2002, 20 February 2002). [Umagico Aboriginal Council

Submission in relation to Cape York Justice Study]. Retrieved from

http://www.parliament.qld.gov.au/documents/TableOffice/TabledPapers/2002/5002T23

$\underline{66 . p d f}$ 
Figure 1.

Indigenous communities and selected towns in Queensland affected by Alcohol Management Plans (AMPs)

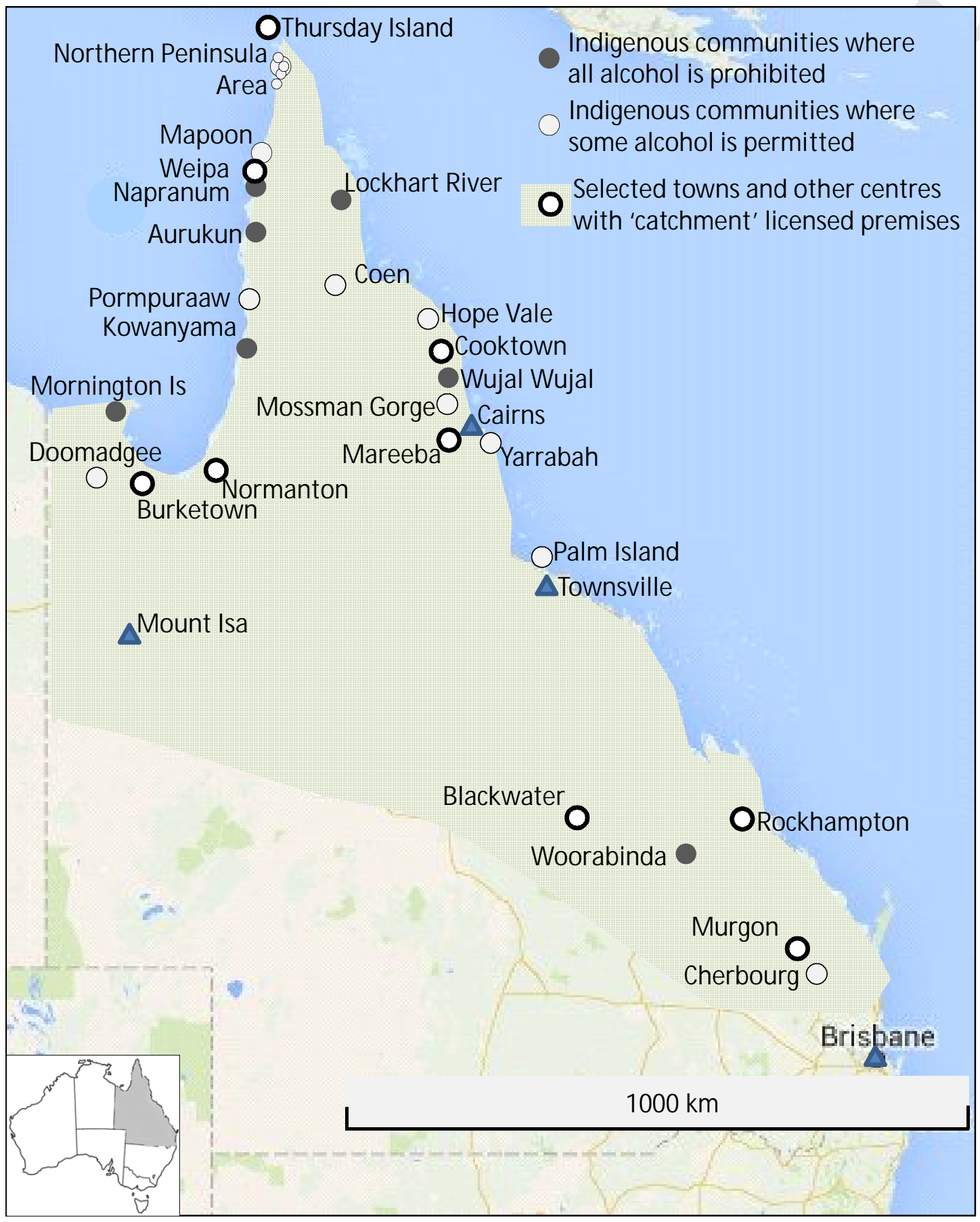


Figure 2

Summary of alcohol restrictions in 19 discrete Indigenous communities in Queensland (Australia) after 2001, arranged according to the timing of the first restrictions and including key policies and programs affecting alcohol availability in these communities and the nearby affected towns.

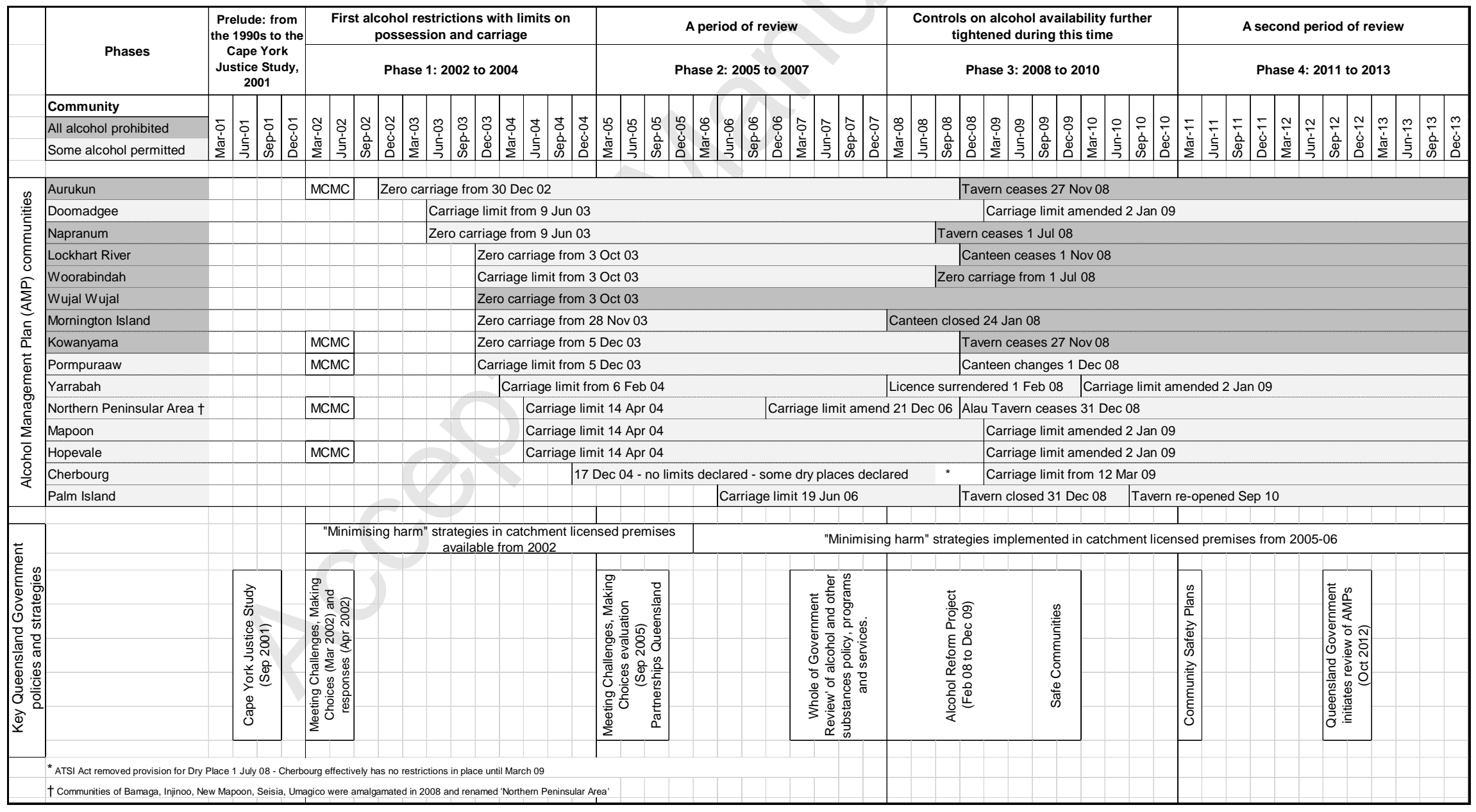

